\title{
Estrous Cycle Ratio as a Reproductive Index in the Rats
}

\author{
MJ Adeniyi ${ }^{1 *}$ and FO Agoreyo ${ }^{2}$ \\ ${ }^{1}$ Department of Physiology, Edo University Iyamho, Nigeria \\ ${ }^{2}$ Department of Physiology, University of Benin, Nigeria
}

*Corresponding author: MJ Adeniyi, Department of Physiology, Edo University Iyamho, Edo state, Nigeria.

To Cite This Article: MJ Adeniyi. Estrous Cycle Ratio as a Reproductive Index in the Rats. AmJ Biomed Sci \& Res. 2019 - 4(2). AJBSR.MS.ID.000772. DOI: 10.34297/AJBSR.2019.04.000772

Received: July 11, 2019 | Published: July 23, 2019

\begin{abstract}
Estrous cycle is an endogenous rhythm. Previously, studies have evaluated and analyzed the cycle based on its regularity and length and diestrus proportion. The aim of the review is to introduce estrous cycle ratio as a reproductive index and highlight its relevance. Twenty murine studies were retrieved from electronic databases published between 1999 and 2019. Estrous cycle ratio was calculated according to the method of [1]. The result shows that the average estrous cycle ratio is 0.81 with a nadir of 0.5 and a zenith of 1.5 . Increase in estrous cycle ratio may signify prolongation of follicular phase length and delay in ovulation. Decrease in estrous cycle ratio may indicate delay in luteal regression with attendant delay in the initiation of new folliculogenesis. Therefore, estrous cycle ratio is an estrous cycle evaluation index.
\end{abstract}

Keywords: Estrous Cycle Ratio; Follicular Phase; Folliculogenesis; Estrous Cycle; Ovulation

\section{Introduction}

Experimental rats are spontaneous ovulators with characteristic short reproductive cycle length lasting 4-5days [2]. Like the menstrual cycle, cyclic changes occur in murine reproductive structures, including the parenchyma of the ovaries-the primary reproductive organ. Examples of such changes are fluctuations in gonadotropin and gonadal hormones, changes in density of uterine glands and cervical mucus and perturbations in $\mathrm{pH}$, sexual receptivity and body temperature [3].

Rats' estrous is divided into four phases based on cell type and density. Proestrus is characterized by squamous epithelial cells. Estrus, metestrus and diestrus are identified and differentiated based on the presence and proportions of cornified cells, leucocytes and squamous epithelial cells. Like menstrual cycle, proestrus is related to pre-ovulatory phase. Metestrus and diestrus are related to post-ovulatory phase [2].

Several studies have evaluated estrous cycle using estrous cycle indices such as estrous cycle length, estrous frequency, estrous phase interval, estrous regularity and diestrus index [1].
The present study looked at the possibility and relevance of using estrous cycle ratio as a reproductive index in murine studies.

\section{Methodology}

Studies were retrieved through electronic databases of English language literature only. Search was achieved through the use of phrases and key words such as estrous cycle, estrous phases, estrus and estrous length. Murine studies published between 1999 and 2019 were selected. Only studies that displayed estrous phases in form of tables were used. Using these criteria, a total of 20 murine studies were selected. For each reviewed article, information was extracted on authorship and year of study.

Only the placebo groups of these studies were analyzed. Calculation of estrous cycle ratio (ECR) was done using the method prescribed by [1].

$$
\mathrm{ECR}=(\text { Proestrus }+ \text { Estrus }) /(\text { Metestrus }+ \text { Diestrus })
$$

\section{Result}

See in the following (Table 1 \& Table 2)

\begin{tabular}{|c|c|c|c|c|c|}
\hline Table 1: Estrous cycle phases. \\
\hline \multirow{2}{*}{ S/N } & \multicolumn{5}{|c|}{ Estrous Cycle Phases } \\
\cline { 2 - 5 } & Proestrus & Estrus & Metestrus & Diestrus & \multirow{2}{*}{ References } \\
\hline 1 & $25.0 \pm 0.3$ & $17.0 \pm 1.8$ & $29.0 \pm 0.3$ & $29.0 \pm 0.3$ & Agoreyo \& Adeniyi [1] \\
\hline
\end{tabular}




\begin{tabular}{|c|c|c|c|c|c|}
\hline 2 & $2.5 \pm 0.34$ & $4.2 \pm 0.2$ & $0.5 \pm 0.2$ & $7.8 \pm 0.3$ & Sortur \& Kaliwal [23] \\
\hline 3 & $6.2 \pm 0.4$ & $5.8 \pm 0.4$ & $4.6 \pm 0.4$ & $3.4 \pm 0.34$ & Hassan, [9] \\
\hline 4 & $25.0 \pm 0.0$ & $25.0 \pm 0.0$ & $25.0 \pm 0.0$ & $25.0 \pm 0.0$ & Oyesola et al. [4] \\
\hline 5 & $26.0 \pm 1.8$ & $24.0 \pm 4.7$ & $18.8 \pm 3.2$ & $33.3 \pm 1.8$ & Mustapha et al. [13] \\
\hline 6 & $1.0 \pm 0.0$ & $2.1 \pm 0.0$ & $1.2 \pm 0.0$ & $4.6 \pm 1.1$ & Ahirwar et al. [8] \\
\hline 7 & $3.8 \pm 0.4$ & $6.2 \pm 1.4$ & $6.0 \pm 1.3$ & $14.2 \pm 2.4$ & Sharanabasappa et al. [19] \\
\hline 8 & $4.0 \pm 0.6$ & $4.8 \pm 0.7$ & $3.5 \pm 0.8$ & $3.7 \pm 0.7$ & Santos et al. [21] \\
\hline 9 & $0.86 \pm 0.1$ & $0.9 \pm 0.1$ & $0.8 \pm 0.1$ & $1.8 \pm 0.5$ & Abu \& Uchendu [7] \\
\hline 10 & $32.0 \pm 0.0$ & $59.0 \pm 0.0$ & $50.0 \pm 0.0$ & $31.0 \pm 0.0$ & Ranjan et al. [22] \\
\hline 11 & $5.0 \pm 0.2$ & $7.7 \pm 0.3$ & $4.9 \pm 0.3$ & $12.3 \pm 0.4$ & Oluyemi et al. [16] \\
\hline 12 & $6.4 \pm 0.2$ & $7.2 \pm 0.2$ & $10.6 \pm 0.2$ & $6.4 \pm 0.2$ & Sarita [18] \\
\hline 13 & $20.9 \pm 0.0$ & $20.0 \pm 0.0$ & $44.8 \pm 0.0$ & $14.3 \pm 0.0$ & Iranloye \& Owokunle [10] \\
\hline 14 & $21.7 \pm 0.0$ & $22.3 \pm 0.0$ & $20.4 \pm 0.0$ & $37.6 \pm 0.0$ & Raji \& Hawt [17] \\
\hline 15 & $4.8 \pm 0.2$ & $6.8 \pm 0.3$ & $5.5 \pm 0.3$ & $10.2 \pm 0.3$ & Sayed et al. [20] \\
\hline 16 & $15.0 \pm 0.0$ & $20.0 \pm 0.0$ & $40.0 \pm 0.0$ & $25.0 \pm 0.0$ & Ngadjui et al. [15] \\
\hline 17 & $5.0 \pm 0.0$ & $7.5 \pm 0.0$ & $2.5 \pm 0.0$ & $12.0 \pm 0.0$ & Nayanaturu et al. [14] \\
\hline 18 & $2.08 \pm 0.5$ & $3.3 \pm 0.3$ & $4.0 \pm 0.3$ & $5.6 \pm 0.4$ & Koneri et al. [12] \\
\hline 19 & $1.8 \pm 0.0$ & $2.9 \pm 0.0$ & $1.3 \pm 0.0$ & $3.5 \pm 0.0$ & Monima et al. [5] \\
\hline 20 & $4.0 \pm 0.0$ & $6.0 \pm 0.0$ & $5.0 \pm 0.0$ & $15.0 \pm 0.0$ & Kage et al. [11] \\
\hline
\end{tabular}

\section{Table 2: Estrous cycle ratio.}

\begin{tabular}{|c|c|c|}
\hline $\mathrm{S} / \mathrm{N}$ & Estrous Cycle Ratio & References \\
\hline 1 & 0.7 & Agoreyo \& Adeniyi [1] \\
\hline 2 & 0.8 & Sortur \& Kaliwal [23] \\
\hline 3 & 1.5 & Hassan [9] \\
\hline 4 & 1 & Oyesola et al. [4] \\
\hline 5 & 1 & Mustapha et al. [13] \\
\hline 6 & 0.5 & Ahirwar et al. [8] \\
\hline 7 & 0.5 & Sharanabasappa et al. [19] \\
\hline 8 & 1.2 & Santos et al. [21] \\
\hline 9 & 0.7 & Abu \& Uchendu [7] \\
\hline 10 & 1.1 & Ranjan et al. [22] \\
\hline 11 & 0.7 & Oluyemi et al. [16] \\
\hline 12 & 0.8 & Sarita [18] \\
\hline 13 & 0.7 & Iranloye \& Owokunle [10] \\
\hline 14 & 0.8 & Raji \& Hawt [17] \\
\hline 15 & 0.7 & Sayed et al. [20] \\
\hline 16 & 0.5 & Ngadjui et al. [15] \\
\hline 17 & 0.9 & Nayanaturu et al. [14] \\
\hline 18 & 0.6 & Koneri et al. [12] \\
\hline 19 & 1 & Monima et al. [5] \\
\hline 20 & 0.5 & Kage et al. [11] \\
\hline
\end{tabular}

\section{Discussion and Conclusion}

During active female reproductive life, cyclical morphological and physiological changes occur in the ovarian parenchyma [3].
Each cycle begins with development of ovarian follicle to graafian follicle which then ruptures under the influence of luteinizing hormone, paving way for corpus luteum formation. The whole 
process involved in corpus luteum formation is termed luteogenesis However, in the absence of fertilization, corpus luteum undergoes luteolysis, a process where luteal cells regress and involute into corpus albican [3].

Over the years, attempt to evaluate estrous cycle using relativity of luteogenesis and luteolysis have been largely unsuccessful $[4,5]$. For example, estrous frequency and regularity, estrous cycle length, estrous phase interval and diestrus index do not provide detailed information about relative durations of folliculogenesis, luteogenesis and luteolysis. The present study demonstrated the relevance of estrous cycle ratio as a predictor of luteogenesis and luteolysis intervals.

Our ECR analysis shows an average value of 0.81 with a nadir of 0.5 and a zenith of 1.5. Increase or decrease in ECR indicates acyclicity. For example, during pregnancy, the presence of hormonal support in form of chorionic gonadotropin facilitates the persistence of luteal cells and delays regression of corpus luteum. High level of progesterone secreted by luteal cells result in feedback inhibition of follicle stimulating hormone, culminating in delay in the initiation of new folliculogenesis. Therefore, as luteal cells persist, a decrease in estrous cycle ratio occurs.

Increase in estrous cycle ratio may signify prolongation of follicular phase length and delay in ovulation. For example, in anovulatory cycle, folliculogenesis occur without substantive luteinization. This results in prolongation of luteogenesis. In many experimental models of anovulatory cycles, a decrease in LH secretion brings about a delay in ovulation and phase transition. In many experimental models of anovulatory cycles, in addition to inadequate luteinization, decrease in expression of kissipeptin has also been documented [6].

While the famous estrous phase interval looks at the average duration of each estrous phase, estrous cycle length examines the average number of days it takes to complete a cycle and diestrus index examines the relation of diestrus phase to other phases [715]. However, estrous cycle ratio is a better predictor of the cyclical phenomenon which takes place in ovarian parenchyma during puberty [16-23]

In conclusion, the study has demonstrated the relevance of estrous cycle ratio as a reproductive index in murine studies.

\section{References}

1. Agoreyo FO, Adeniyi MJ (2018) Pattern of Estrous Cycle and Ovarian Antiperoxidative Activity in Light Deprived Sprague-Dawley Rats Treated with Sodium Selenate. J Med Res Biol Stud 1: 103.

2. Marcondes FK, Bianchi FJ, Tanno AP (2002) Determination of estrous cycle phases of Rats: Some helpful considerations. Braz J Biol 62(4a): 609-614.

3. Barrett Kim E, Susan M Barman, Scott Boitano, Heddwen L Brooks (2010) Ganong's Review of Medical Physiology (23 ${ }^{\text {rd }}$ edn). MC graw Hills, New York. 421: 391-427.

4. Oyesola T0, Okoye CS (2010) Effects of Aqueous Extract of Aspilia Africana on Reproductive Functions of Female Wistar Rats'. Pakistan Journal of Biological Sciences 13(3): 126-131.
5. Monima Lemuel Ann, Muhammad Buhari, Sodiq Lawal, Echoru Isaac, Ssempijja Fred, et al. (2019) Effect of Cleome Gynandra Leaf Extract on the Estrous Cycle and Histology of the Ovary and Uterus of Wistar Albino Rats. Anatomy Journal of Africa 8(1): 1385-1394.

6. Boden MJ, Varcoe TJ, Kennaway DJ (2013) Circadian regulation of reproduction: from gamete to offspring. Prog Biophys Mol Biol 113(3): 387-397.

7. Abu AH, Uchendu CN (2011) Effect of aqueous ethanolic extract of Hymenocardia acida stem bark on oestrous cycle of albino rats. Journal of Medicinal Plants Research 5(8): 1280-1283.

8. Dheeraj Ahirwar, Bharti Ahirwar, MD Kharya (2010) Effect of ethanolic extract of Jatropha curcus seeds on estrus cycle of female albino rats. Der Pharmacia Lettre 2(6): 146-150.

9. Hassan, Auta T (2016) Alteration in oestrus cycle and implantation in Mus musculus administered aqueous wood ash extract of Azadirachta indica (neem). Asian Pacific Journal of Reproduction 5(3): 188-192.

10. Iranloye B, Owokunle B (2008) Effect of Garcinia Kola Seed Extract on Female Reproductive Functions in Rats. International Journal of Pharmacology 4(4): 276-281.

11. s Devendra, N Vijaykumar Malashetty, YN Seetharam, P Suresh, Saraswati B Patil (2009) Effect of Ethanol Extract of Whole Plant of Trichosanthes cucumerina var. cucumerina L. on Gonadotropins, Ovarian Follicular Kinetics and Estrous Cycle for Screening of Antifertility Activity in Albino Rats. Int J Morphol 27 (1): 173-182.

12. Koneri R, Balaraman R, Saraswati CD (2006) Antiovulatory and abortifacient potential of the ethanolic extract of roots of Momordica cymbalaria Fenzl in rats. Indian J Pharmacol 38 (2): 111-114.

13. Mustapha AR, Bawa EK, Ogwu D, Abdullahi US, Kaikabo AA, et al. (2011) Effects of ethanolic extract of Rjynchosia sublobata (Schumach) Meikle on estrous cycle in wistar rats. Int J Med Arom Plants 1(2): 122-127.

14. Nayanaturu AK, Akshatha Alva, Sharannya Kottari, Anwar Amemar Soofi, Rejeesh EP, et al. (2012) Effect of Cynodon Dactylon Extract on Estrous Cycle and Reproductive Organs in Female Wistar Rats. International Journal of Analytical, Pharmaceutical and Biomedical Sciences 1(3): $1-10$.

15. Ngadjui Esther, Watcho Pierre, Benoit Telesphore Nguelefack, Kamanyi Albert (2013) Effects of Ficus asperifolia on normal rat estrus cyclicity. Asian Pac J Trop Biomed 3(1): 53-57.

16. Oluyemi KA, Okwuonu UC, Baxter DG, Oyesola TO (2007) Toxic effects of methanolic extract of Aspilia safricana leaf on the estrous cycle and uterine tissues of wistar rats. Int J Morphol 25(3): 609-614.

17. Raji Y, Hart VO (2012) Influence of prolonged exposure to Nigerian Bonny light crude oil on fertility indices in rats. Niger J Physiol Sci 27(1): 55-63.

18. Sarita M (2018) Antifertility Activity of Eugenia Jambolana Seed Extract in Female Albino Rat. Biochem Physiol 7(2): 237

19. Sharanabasappa A, Vijayakumar B, Saraswati B Patil (2002) Effect of Momordica charantia Seed Extracts on Ovarian and Uterine Activities in Albino Rats. Pharmaceutical Biology 40(7): 501-507.

20. Sayed Bakry, Hassan Abdalkader M, Shahat Mohamed MA, Abdullah Ahmed (2010) Effect of Depo-Provera on Estrous Cyclicity, Serum Proteins and Lipid Profile in Mice. World Applied Sciences Journal 8(9): 1042-1049

21. Santos Denise Barbosa, Jamylla Mirck Guerra de Oliveira, Martins Neto Bueno, Paulo Alex Bezerra Sales, Charllyton Luis Sena Costa, et al. (2015) Effects of ethanol extract of Cenostigma macrophyllum Tul. (caneleiro) on reproductive parameters of female rats. Revista cubana de plantasas medicinales 20(3): 265-276.

22. Ranjan Pradhan Manas, Mohanty Manjushree, Mohapatra Sabita, Sahoo Samira (2013) Antifertility Effect of Alcoholoc Stalk Extract of Piper 
betel Linn on Female Albino Rats. International Reseasrch Journal on Pharmacy. 4(1).
23. Sortur SM, Kaliwal BB (1999) Effect of methyl parathion formulation on estrous cycle and re rreproductive performance in albino rats. Indian Journal of Experimental Biology 37(2): 176-178. 